\title{
Nutrient retention in a microcatchment with low levels of anthropogenic pollution
}

\section{Retención de nutrientes en una microcuenca con bajos niveles de contaminación antropogénica}

\author{
Jaime G Cuevas a,c,f*, Jenny Huertas ${ }^{b}$, César Leiva ${ }^{c}$, Leandro Paulino d,f, José Dörner c,f, José L Arumí e \\ *Corresponding author: ${ }^{a}$ Instituto de Investigaciones Agropecuarias, Oficina Técnica Los Ríos, \\ Campus Isla Teja s/n, Valdivia, Chile, tel.: +56 63 2293040, fax +56 63 2221460, jxcuevas@inia.cl \\ ${ }^{\mathrm{b}}$ Universidad Austral de Chile, Facultad de Ciencias, Escuela de Graduados, \\ Magíster en Ciencias, Mención Recursos Hídricos, Valdivia, Chile. \\ ${ }^{c}$ Universidad Austral de Chile, Facultad de Ciencias Agrarias, Instituto de Ingeniería Agraria y Suelos, Valdivia, Chile. \\ ${ }^{d}$ Universidad de Concepción, Facultad de Agronomía, Chillán, Chile.

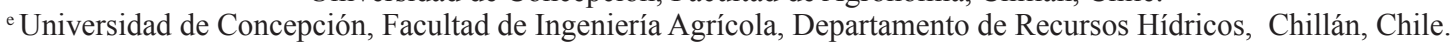 \\ ${ }^{\mathrm{f}}$ Universidad Austral de Chile, Centro de Investigación en Suelos Volcánicos, Valdivia, Chile.
}

\begin{abstract}
SUMMARY
Streamside native forests filter nutrients and sediments from extra-riparian environments. Most related studies have been carried out in environments chronically polluted by nutrients, making it difficult to assess whether the detected patterns would hold in less polluted areas, such as Chile. However, there are no studies about Chilean natural streamside vegetation ability to filter nutrients and sediment. We hypothesized that southern Chilean streamside forests efficiently retain nutrients due to their, previously documented, tight nitrogen cycle especially in terms of fixation, mineralization and plant uptake, in addition to the high phosphorus adsorption by volcanic soils and high cation retention due to the expected higher cationic exchange capacity (CEC) in floodplains. We studied a fluvial terrace with grasslands covering the uplands, a forest on a slope, and a floodplain with native trees adjacent to a creek. We laid out nine parallel transects in the aforementioned environments and installed five wells in each transect. We extracted and analyzed groundwater three times a year, finding that the nitrate concentration decreased in the transect from the grassland to the floodplain forest. Ammonium, calcium, potassium, and electrical conductivity increased in the same transect, but these variables were always higher than those in the stream. Moreover, soil chemical determinations showed that ammonium, basic cations, aluminum, aluminum saturation and organic matter increased significantly in the floodplain soil compared to the grassland soil. The CEC was marginally different in the studied transects. We conclude that native forest ecosystems constitute effective filters for the studied nutrients, highlighting the associated soils role.
\end{abstract}

Key words: cationic exchange capacity, groundwater, nitrogen cycle, phosphorus adsorption, riparian zones.

\section{RESUMEN}

Los bosques nativos adyacentes a arroyos filtran nutrientes y sedimentos que vienen desde ambientes extrarribereños. La mayoría de los estudios relacionados han sido realizados en ambientes contaminados crónicamente con nutrientes, dificultando evaluar si los patrones detectados se mantendrían en áreas menos contaminadas, como Chile. Sin embargo, no hay estudios acerca de la habilidad de la vegetación natural chilena adyacente a arroyos para filtrar nutrientes y sedimentos. Se hipotetiza que los bosques ribereños chilenos retienen eficientemente los nutrientes debido al ciclo de nitrógeno ajustado, documentado previamente, especialmente en fijación, mineralización y absorción vegetal; a la alta adsorción de fósforo por los suelos volcánicos, y a la alta retención de cationes debida a la esperada superior capacidad de intercambio catiónico (CIC) en las planicies de inundación. Se estudió una terraza fluvial con praderas cubriendo las zonas altas, bosque en la pendiente y una planicie de inundación con árboles nativos adyacentes a un arroyo. En nueve transectos paralelos en los ambientes mencionados, fueron perforados cinco pozos en cada uno. Se extrajo y analizó el agua subterránea tres veces en un año, encontrando que su concentración de nitrato decreció en el transecto desde pradera a bosque ribereño. El amonio, calcio, potasio y la conductividad eléctrica aumentaron en el mismo transecto, pero estas variables fueron siempre superiores que en el arroyo adyacente. Las determinaciones químicas del suelo mostraron que el amonio, los cationes básicos, el aluminio y la saturación de este aumentaron significativamente en el suelo de la planicie de inundación comparado al suelo de las praderas. La CIC fue marginalmente diferente en los transectos estudiados. Se concluye que los ecosistemas forestales nativos son un filtro efectivo para los nutrientes estudiados, destacándose el rol de los suelos asociados.

Palabras clave: adsorción de fósforo, agua subterránea, capacidad de intercambio catiónico, ciclo del nitrógeno, zonas ribereñas.

\section{INTRODUCTION}

Land cover is one of the principal determinants of stream/ groundwater quality and streamflows exported by a water- shed (Hedin et al. 1995). In microcatchments the influence of vegetation cover or land uses is even more important, especially the location and spatial arrangement of vegetation patches within the watershed (Strayer et al. 2003). Ripa- 
rian vegetation is easy to distinguish in this context since it grows along corridors parallel to streams, which are clearly visible in anthropogenic landscapes. Riparian vegetation is considered an important control element of biogeochemical cycles since it forms an interface between terrestrial and aquatic systems, retaining sediments that would otherwise enter streams; thus regulating stream temperature, controlling the hydrological regime and stabilizing riverbanks (Lowrance 1998). It is also considered a natural buffer capable of filtering the influences from extra-riparian environments (Lowrance 1998). In addition, floodplains soils also act as nutrient accumulators (Noe and Hupp 2005). The importance and function of these kinds of ecosystems have been recognized in North America and Europe for several decades. However, most studies have been carried out in environments with chronic deposition of nutrients and pollutants (Lowrance 1998, Dhondt et al. 2006), making it difficult to assess whether the detected patterns would hold in less polluted areas. For example, countries as Chile have comparatively low levels of pollution in rural and natural landscapes (Weathers et al. 2000), but there are still no studies about natural streamside ${ }^{1}$ vegetation ability to filter nutrients and sediment.

Some particularities of pristine southern Chilean ecosystems have been reported, such as a very tight nitrogen cycle characterized by relatively low fixation rates (Pérez et al. 2003) and a higher organic nitrogen input and output rates (Hedin et al. 1995, Weathers et al. 2000). Moreover, net nitrogen mineralization is comparatively low (Pérez et al. 2003) consisting of a very efficient process with scarce inorganic nitrogen losses into streams (Hedin et al. 1995). Thus, plants readily use the low soil nitrogen levels. Regarding southern Chilean volcanic soils, non-crystalline materials and humus define the andic properties of these soils, which are unique, and differentiate them from other soil types, e.g. variable charge, low bulk density, high hydraulic and air conductivity, among other characteristics (Dörner et al. 2009). Furthermore, these soils also have a very high capacity of phosphorus adsorption due to their aluminum and hydrous oxide composition (Alfaro et al. 2008). On the other hand, the anthropogenic replacement of upland forests by grasslands should produce a difference in carbon accumulation in soil, which should be more elevated in forests still growing in the floodplains. Moreover, clay accumulation here should be higher due to the fine material input resulting from flooding (Naiman et al. 1998).

Based on these conditions, we expect to find some soil variability even in edaphically homogeneous geographical zones, due to different land uses/covers, microclimatic gradients, topography and the contrasting effects of stream water on uplands versus floodplains. This should result in different nutrient retention potentials along a transect from grasslands to streamside forests. Specifically, we tested the

This concept includes both riparian vegetation and forests located on slopes above floodplains (Study site section). following hypotheses: i) effective nitrogen retention is associated with second-growth forests growing in streamside zones, considering the active growth and root scope of developing stands; these forests represent a major sink for this nutrient as compared to grasslands; ii) we expect phosphorus adsorption in volcanic soils to decrease the amount of dissolved phosphorus leached into groundwater in streamside zones; and iii) we expect the retention of basic cations to be higher in streamside environments due to the foreseen higher cationic exchange capacity associated with clay and organic matter accumulation in floodplains (Brady and Weil 2004).

The objective of this paper is to make use of the comparatively well conserved, lesser polluted environments of southern Chile, along with the special characteristics of these soils, to evaluate the role of Chilean temperate forests as a filter for nutrients directed towards streams from neighboring livestock and agricultural fields. Our main approach consisted in the study of upland influences whose water and nutrient fluxes are perpendicular to the stream; these are discussed later in the context of micro-catchment headwater influences.

\section{METHODS}

Study site. We worked at the Austral Experimental Livestock and Agriculture Station, located in Los Ríos Region in southern Chile (39 $46^{\prime} 55^{\prime}$ ' S, 73 $3^{\circ} 13^{\prime} 24^{\prime}$ ' W, figure 1), $4 \mathrm{~km}$ north of the city of Valdivia. The climate is humid temperate (Amigo and Ramírez 1998), with an average annual temperature of $12{ }^{\circ} \mathrm{C}$, with reduced thermal amplitude due to the proximity to the Pacific Ocean and to several lakes. The region average annual rainfall is 2,500 $\mathrm{mm}$, with heavy rainfalls concentrated in the winter. The soil corresponds to an Andisol, Valdivia series (Duric Hapludand or a Petroduri-Silandic Andosol, WRB 2006).

We studied a $200 \mathrm{~m} \times 75 \mathrm{~m}$ portion of terrain adjacent to the third order Santa Rosa stream (figure 1). This stream is 5-6 m wide with a stream flow of $150-990 \mathrm{~L} \mathrm{~s}^{-1}$ (December 2012 and July 2013, respectively). A layer of loose sediment is found on the streambed. The creek forms part of a watershed whose approximate area is $5 \mathrm{~km}^{2}$ and that flows through the middle of a $250 \mathrm{~m}$-wide native forest. Beyond the native forest, livestock, agriculture fields, dispersed houses and a very small portion of exotic tree plantations make up the remaining area.

The geomorphology is a typical fluvial terrace, with the studied uplands covered by a $30 \mathrm{~m}$-wide grassland. Then, a forested slope ( $25 \mathrm{~m}$ wide, $35^{\circ}$ inclination) connects with the floodplain, also covered by native forest, with a width of $20 \mathrm{~m}$ (figure 2). Santa Rosa stream marks the boundary of this part of the floodplain, but the plain continues beyond the other riverbank. The grasslands are located about $17 \mathrm{~m}$ a.s.l., while the stream is located 13 $\mathrm{m}$ below the grasslands. The floodplain is inundated to a depth of $40 \mathrm{~cm}$ above ground level from May to October and has sporadic lapses of surface water recession, which depends on the watershed rainfall regime. 


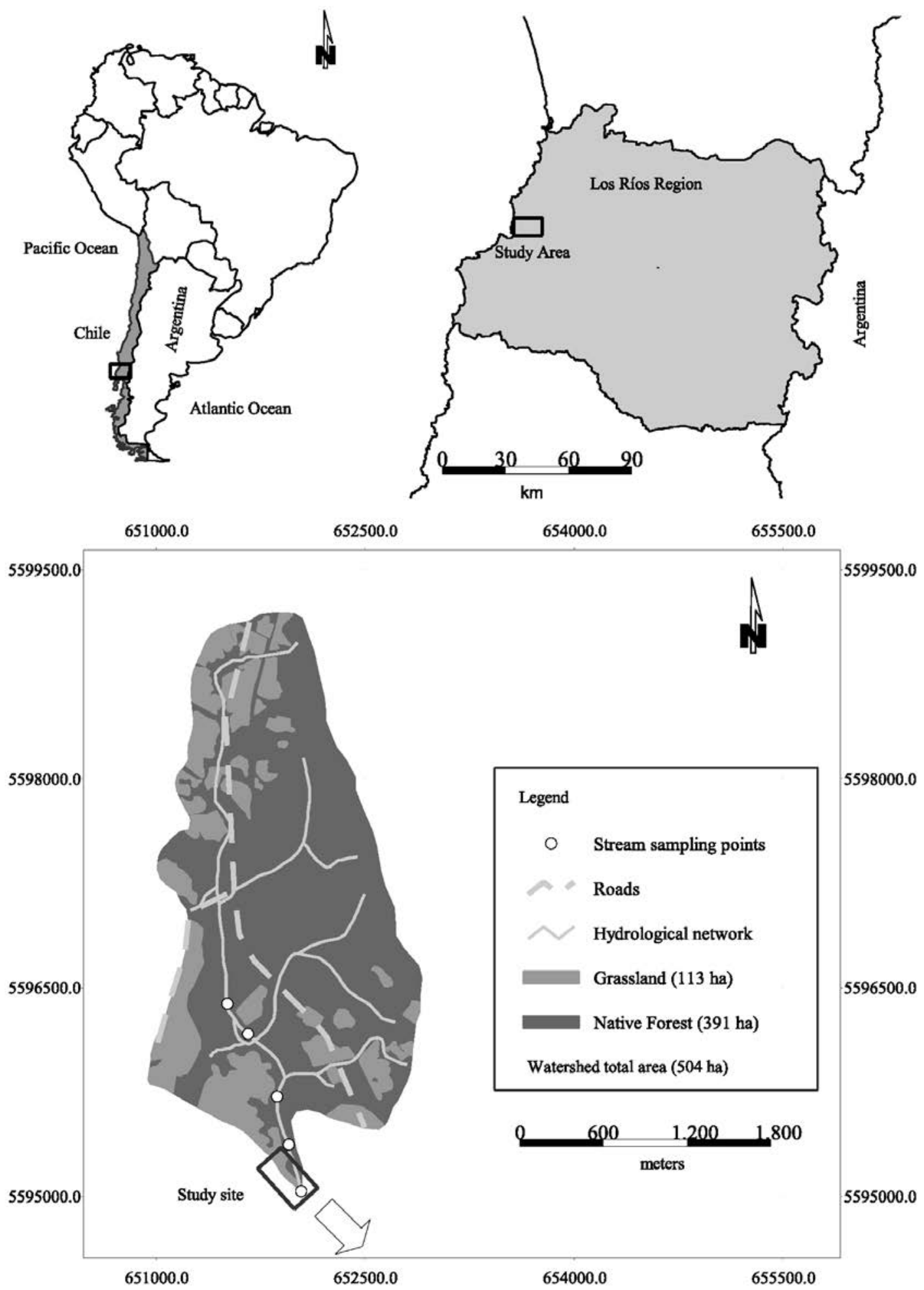

Figure 1. General location of the study site. The arrow indicates streamflow direction.

Ubicación general del sitio de estudio. La flecha indica la dirección del caudal superficial.

The present plant cover was sown in April 2011 with Lolium perenne L. (perennial ryegrass), after an application of 2,000 kg ha-1 $\mathrm{CaCO}_{3}$. No fertilization was applied until October 2012. Grasslands were not grazed, but upon reaching $30 \mathrm{~cm}$ of height, they were cut by a mower, and the residue was discarded elsewhere.

The forested slope is dominated by second-growth native forests of Nothofagus obliqua (Mirb.) Oerst. var. 


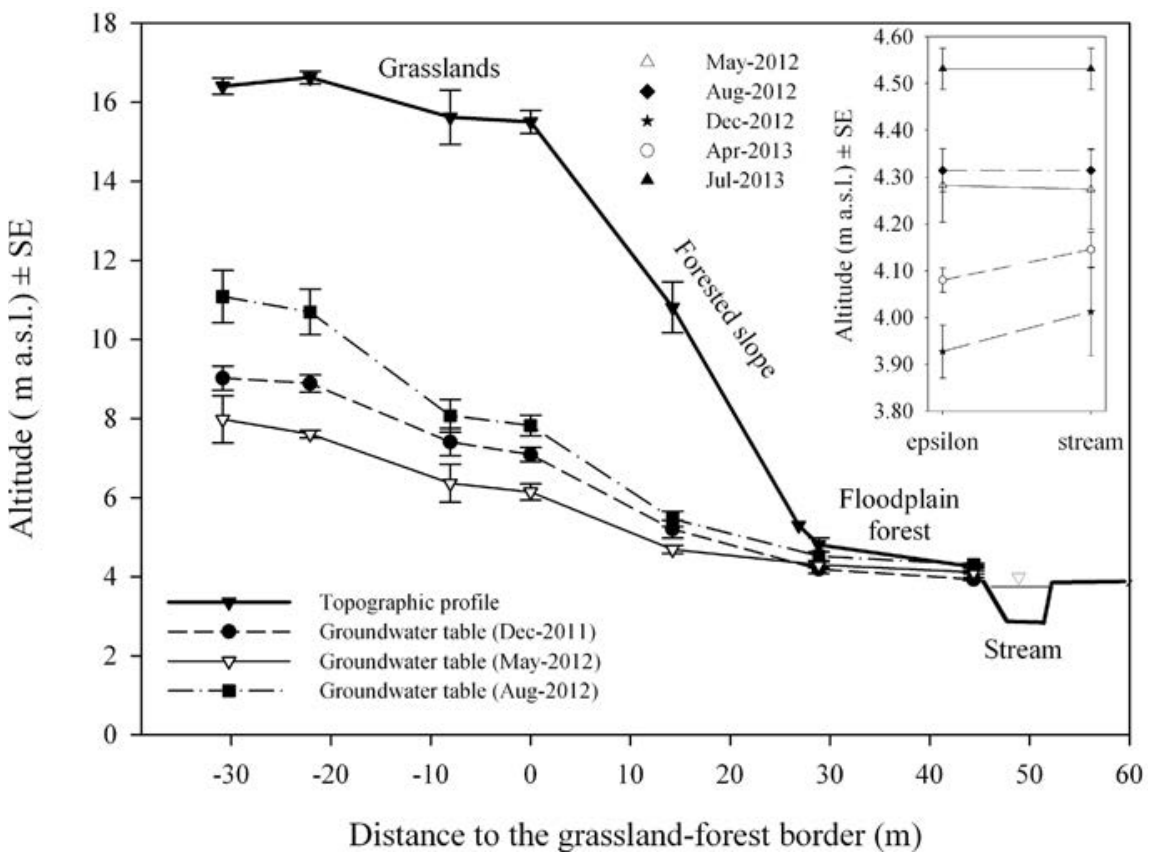

Figure 2. Topographic profile of the study site shows the position of the groundwater table at different dates. The insert graph shows the gradient between the well that is adjacent to the stream (epsilon) and the stream itself. SE = standard error.

Perfil topográfico del sitio de estudio, mostrando la posición del espejo de agua subterránea para diferentes fechas. El gráfico inserto muestra el gradiente entre el pozo adyacente al arroyo (epsilon) y el arroyo. SE = error estándar.

obliqua tree, Chusquea quila Kunth (bamboo) and Hedera helix L., an exotic vine. It is mainly N. obliqua which corresponds to the previous vegetation that dominated the area used for livestock activities. This is not riparian vegetation, but a zone presenting an elevation higher than that of the floodplain. The riparian vegetation found here is characterized mainly by Blepharocalyx cruckshanksii $(\mathrm{H}$. et A.) Nied., Myrceugenia exsucca (DC.) Berg and Drimys winteri J. R. et G. Forster var. chilensis (DC.) A. Gray native trees, with few individuals of $N$. obliqua. In this geomorphologic zone, this kind of vegetation is locally referred to as "hualve". The conservation status of the studied vegetation is good, especially in the floodplain.

Soil analyses. Soil chemistry was analyzed because it is a key determinant of groundwater quality. With a $21 \mathrm{~mm}$ diameter auger, we took 20 random subsamples in November 2011 from the soil surface $(0-20 \mathrm{~cm}$ depth$)$ of three $30 \mathrm{~m}$ wide plots, not only in the grassland, but also in the forested slope and floodplain as well. Given the patterns observed for groundwater quality, we decided to resample the floodplain with more detail in October 2012, close to $\delta$ and $\varepsilon$ wells (for well denomination, see the following section, figure 3), in addition to grassland and slope environments. Therefore, we show October results obtained from the most thorough survey. Moreover, in May 2013 we sampled the sediment found on the streambed at three points. Grasslands had been fertilized twice with cattle slurry after October 2012 and before May 2013, but we consider that nutrient concentration in the streambed was not affected because changes were not detected in groundwater quality after fertilization ${ }^{2}$. The 20 soil subsamples were combined to produce a composite sample for each plot and environment, thus the sample size was three. Analyzed variables were $\mathrm{pH}$, organic matter, nitrate, ammonium, Olsen phosphorus and exchangeable calcium, potassium, sodium, magnesium, aluminum, bases and aluminum saturation, and extractable aluminum. Cationic exchange capacity (CEC, $\mathrm{CaCl}_{2}$ method) was also determined, at the $\mathrm{pH}$ found in soil instead of at $\mathrm{pH}=7.0$, because the former is a more accurate expression of the soil capacity to retain cations. Analyses followed the methods reported by Sadzawka et al. (2006). Soil texture was analyzed using the hydrometer method (Forsythe 1974); after the organic matter was destroyed, cemented agents were eliminated and clay was dispersed.

Well construction. A grid of 45 wells was established throughout the study area to assess nutrient removal by pastures, forest vegetation and soils. Wells were located as nine parallel transects (but perpendicular to the stream) in the grassland (named $\alpha$ wells) and the grassland-forest border $(\beta), 15 \mathrm{~m}$ from the border on the forested slope $(\gamma)$, and $30(\delta)$ and $45 \mathrm{~m}(\varepsilon)$ from the same border, corresponding to the floodplain (figure 3 ). The $\varepsilon$ wells were adjacent to the stream. Moreover, the nine $\alpha$ wells were established at different distances within the grassland: three at $7.5 \mathrm{~m}$, three at $22.5 \mathrm{~m}$ and three at $31 \mathrm{~m}$ from the forest border.

Huertas J. Unpublished thesis. Facultad de Ciencias, Universidad Austral de Chile. 


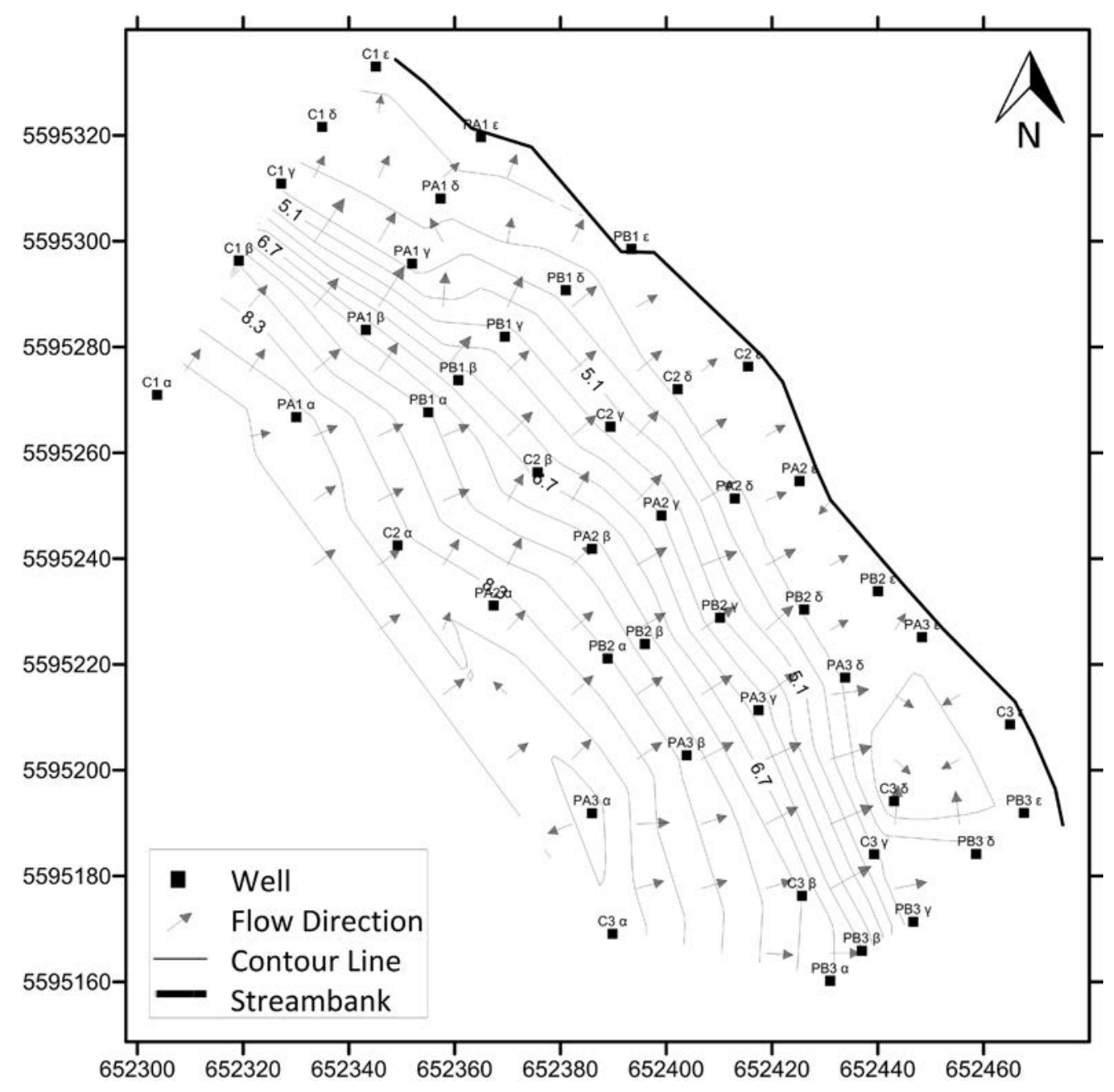

Figure 3. Isolines for groundwater movement in December 2011. Numbers on the left correspond to the groundwater table altitude in meters above sea level. The $\alpha, \beta$ wells were located in the grassland, $\gamma$ on the forested slope, and $\delta, \varepsilon$ in the floodplain forest. The other codes (e.g., C1, PA3, etc.) were used for well identification. UTM coordinates are in meters.

Isolíneas de movimiento del agua subterránea en diciembre 2011. Los números a la izquierda corresponden a la altitud del espejo de agua en metros sobre el nivel del mar. Los pozos $\alpha, \beta$ estaban localizados en la pradera, $\gamma$ en la ladera forestada, y $\delta, \varepsilon$ en la planicie de inundación. Los otros códigos (ejemplo: C1, PA3, etc.) fueron para la identificación de los pozos. Las coordenadas UTM están en metros.

Wells (10 cm diameter) were perforated with manual augers up to $11.75 \mathrm{~m}$ below ground in the grassland, up to $10 \mathrm{~m}$ on the slope, and up to $2 \mathrm{~m}$ on the floodplain, depending on the groundwater depth. Wells were cased with 7.5 $\mathrm{cm}$-diameter PVC tubes, and were screened at the following distances measured from the bottom: $185 \mathrm{~cm}$ ( $\delta$ and $\varepsilon$ wells), $274 \mathrm{~cm}$ ( $\gamma$ wells) and $385 \mathrm{~cm}$ ( $\alpha$ and $\beta$ wells). The screened section was enveloped with a thin fabric (openings $200 \mu \mathrm{m}$ ) to prevent blockage by incoming sediments. The borehole was then sealed with a mixture of gravel and sand (32\% porosity). Finally, the top $25 \mathrm{~cm}$ were sealed with swelling bentonite ( $12.5 \%$ volume/volume mixed with soil).

The groundwater level below ground was recorded with a measuring tape several times a year, and its elevation was calculated by deducting this distance from the elevation at ground level.
Groundwater chemistry. One to two days prior to water sampling, all of the 45 wells were purged with either a water pump or a retention valve screwed to a thin PVC tube introduced into the water (DGA 2007). Groundwater was collected from the water table in December 2011, May and August 2012, with a bottle attached to a long PVC pipe. Different bottles were used for each sampled well to avoid water cross-contamination. The water content was then transferred to another bottle that had previously been washed with chlorhydric acid in distilled water $(5$ $\% \mathrm{v} / \mathrm{v})$. Afterwards, $1,250 \mathrm{~mL}$ samples were taken, the capped bottles were kept at cool temperatures (below 5 ${ }^{\circ} \mathrm{C}$ ) and the samples were frozen within $10 \mathrm{~h}$ of being collected. Santa Rosa stream water was also collected; two samples were extracted few meters up and downstream of the studied zone. Samples were analyzed following APHA 
(2005) procedures. Analyzed chemicals were nitrate, nitrite, ammonium, total dissolved nitrogen, dissolved organic nitrogen (calculated as the difference of the total dissolved nitrogen and the inorganic nitrogen forms), phosphate, calcium, potassium and sulfate. Lastly, natural levels of chloride and bromide were used as hydrological tracers, in order to detect dilution or concentration patterns in nutrient concentrations irrespective of plant/microbial uptake. Detection limits were $2 \mu \mathrm{g} \mathrm{L}^{-1}$ (nitrate-N and phosphate-P), $3 \mu \mathrm{g} \mathrm{L}{ }^{-1}$ (ammonium-N), $190 \mu \mathrm{g} \mathrm{L}{ }^{-1}$ (total dissolved nitrogen), $50 \mu \mathrm{g} \mathrm{L} \mathrm{L}^{-1}$ (calcium and potassium), $40 \mu \mathrm{g} \mathrm{L}-1$ (bromide), $430 \mu \mathrm{g} \mathrm{L}^{-1}$ for sulfate and $1 \mathrm{mg} \mathrm{L}^{-1}$ for chloride.

Groundwater electrical conductivity was measured in situ with a multi 340i probe (WTW $\mathrm{GmbH}$, Weilheim, Germany) in May and August 2012, after 0-5 days of purging the wells at the groundwater table. Electrical conductivity was also measured on the creek surface.

Nutrient variations along the stream. In order to study the variations of nutrient concentrations upstream from the studied site, we took duplicate water samples in Santa Rosa creek in May 2013 along a 2,000 m transect measured from the watershed outlet upstream (figure 1). This accounted for $40 \%$ of the creek length. Monitoring points were 500 $\mathrm{m}$ apart, and they were sampled downstream in a lapse of 7.5 hours, close to the water travel time in the same transect (5.5 hours).
Data analyses. Soil variables were compared among environments (grassland, forested slope, floodplain, and streambed) and/or depths, by using ANOVA (one-way or two-way). Log and arcsine transformations were calculated to satisfy ANOVA assumptions. When these were not met, the Kruskal-Wallis test was used for the one-way analysis, while a non-parametric two-way ANOVA was performed in the other case (that is, the Scheirer-Ray-Hare extension of the Kruskal-Wallis test; Sokal and Rohlf 1995, p. 446). A posteriori comparisons consisted of the Tukey (for ANOVA) and the non-parametric Fisher's Least Significant Difference (LSD) tests after the Kruskal-Wallis test.

The relationship between nutrient concentration and the position of water sampling in the stream transect was tested by means of a simple linear regression. All statistical analyses were carried out with Statistica 6.0 software (StatSoft Inc., Tulsa, Oklahoma, USA).

\section{RESULTS}

Soil analyses. Soil organic matter, which was sampled at different depths, showed a variation among environments and at varying soil depths (figure 4) (Two-way ANOVA; $\left.\mathrm{F}_{\text {environment }}=112, \mathrm{~F}_{\text {depth }}=1294, P<0.001, \mathrm{df}=2,18\right)$. Soil organic matter clearly decreased with increasing depth, but the environment effect was not as easily observed because there was a significant interaction between both variables

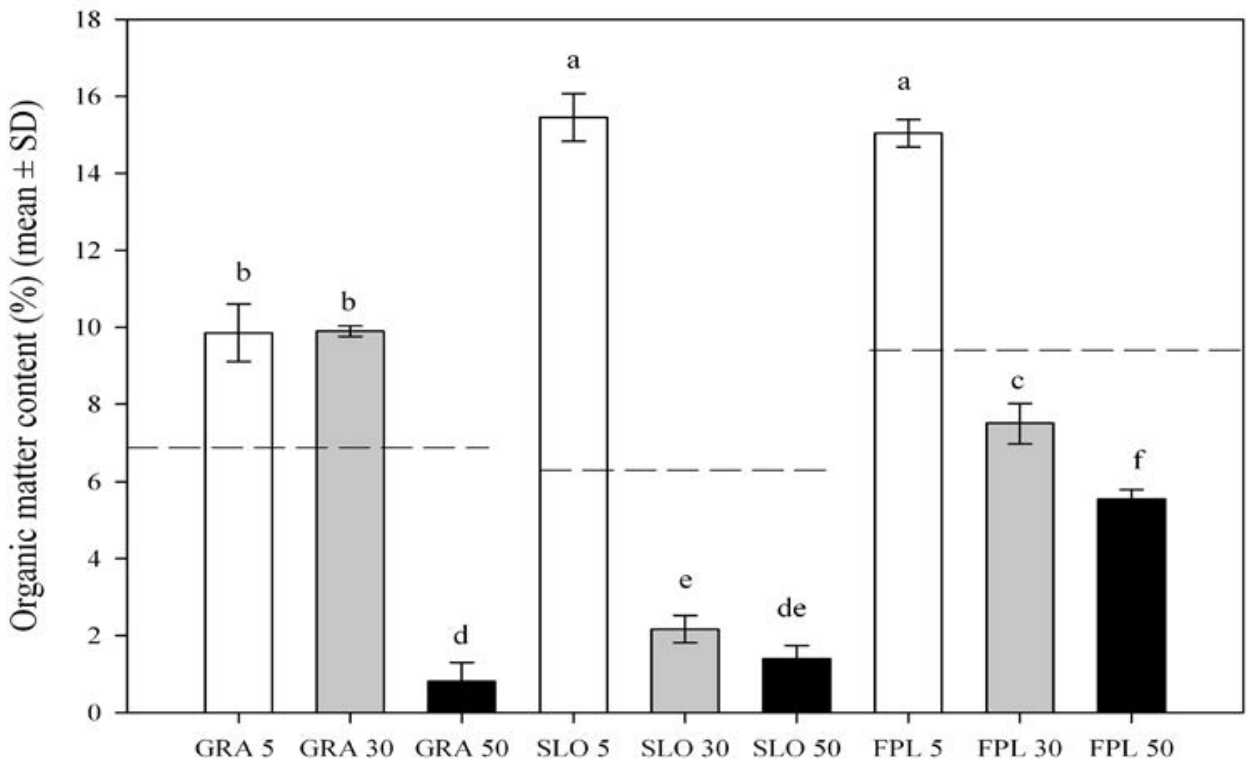

Position in the transect

Figure 4. Soil organic matter content as a function of environment and soil depth. GRA = grasslands, SLO = forested slope, and $\mathrm{FPL}=$ floodplain (the numbers refer to soil depths below ground in $\mathrm{cm}$ ). Dashed lines represent the averages for each environment, irrespective of soil depth. Superscripts indicate significant differences at $P<0.04$ for every comparison possible (Tukey test).

Contenido de materia orgánica del suelo en función del ambiente y profundidad del suelo. GRA $=$ praderas, SLO $=$ ladera forestada y FPL $=$ planicie de inundación (los números se refieren a profundidades de suelo en $\mathrm{cm}$ ). Las líneas discontinuas representan los promedios para cada ambiente, independiente de la profundidad del suelo. Los superíndices indican diferencias significativas a $\mathrm{P}<0,04$ para cada comparación posible (prueba de Tukey). 
$\left(\mathrm{F}_{\text {environment } x \text { depth }}=173, P<0.0001, \mathrm{df}=4,18\right)$. Mean soil organic matter values were very similar between the grassland and the forested slope, but they were significantly lower than in the floodplain soil (figure 4, $P=0.0001$, Tukey test).

Nitrate content increased towards the floodplain, but not significantly (log-transformed data; $\left.\mathrm{F}_{4,10}=1.6, P=0.23\right)$. Ammonium content was maximal close to $\varepsilon$ wells and on the streambed (log-transformed data; $\mathrm{F}_{4,10}=12.7, P<0.001$ ). There was more Olsen phosphorus in the grassland and on the streambed $\left(\mathrm{F}_{4,10}=17.4, P<0.001\right)$ (figure $\left.5 \mathrm{~A}\right)$. Basic cations, the sum of bases, and exchangeable aluminum also increased numerically towards the floodplain, reaching their highest levels close to $\delta$ or $\varepsilon$ wells, which were not statistically different among them, but were almost always distinct from grassland plots $\left(\mathrm{F}_{4,10}>4.6, P<0.03\right.$; Kruskal-Wallis test: $\mathrm{H}_{4,15}=10.7$, $P=0.03$ ) (figure 5B). Soil acidity significantly increased along the transect, starting with $\mathrm{pH}$ levels of 5.7 in the grasslands and reaching the highest levels close to the $\varepsilon$ wells $(\mathrm{pH}=5.0)$
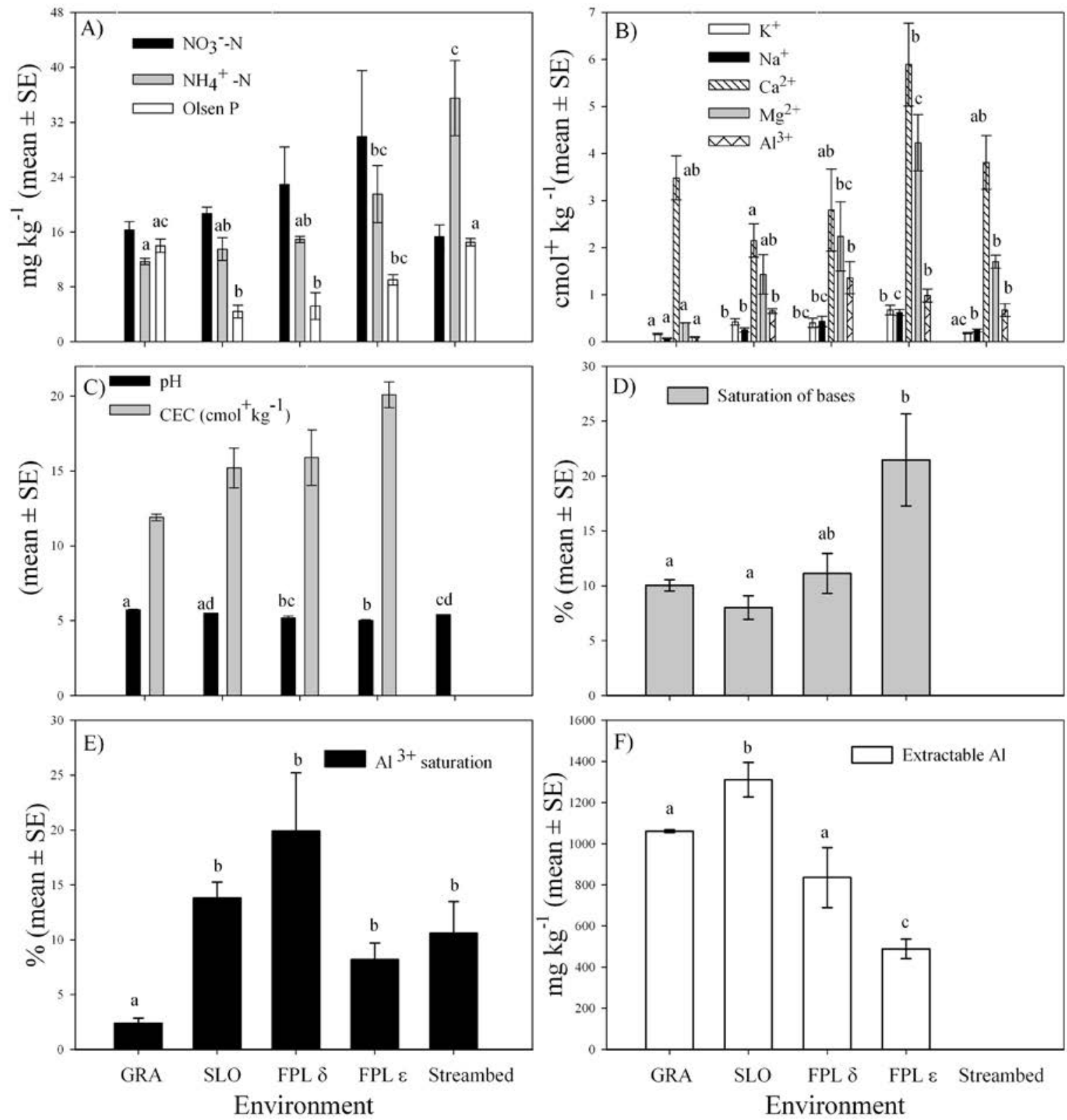

Figure 5. Studied sites' soil chemical composition. CEC = cationic exchange capacity at soil pH. Different superscripts indicate significant differences at $P<0.05$ according to the Tukey test (Fisher's LSD test for the Mg and extractable Al analyses). Note that the Y-axis scales are different in magnitude. CEC and extractable Al were not determined at the streambed.

Composición química del suelo de los sitios de estudio. $\mathrm{CEC}=$ capacidad de intercambio catiónico al pH del suelo. Diferentes superíndices indican diferencias significativas a $P<0,05$ de acuerdo a la prueba de Tukey (mínima diferencia significativa de Fisher para magnesio y aluminio extractable). Notar que las escalas del eje Y difieren en magnitud. La CEC y el aluminio extractable no fueron determinados en el lecho del arroyo. 
$\left(\mathrm{F}_{4,10}=18.2, P<0.001\right)$. CEC did not show any significant variation $\left(\mathrm{F}_{3,8}=2.6, P=0.12\right)$ (figure $5 \mathrm{C}$ ). Bases saturation, which reached more than $80 \%$, was maximal in the grassland, in $\varepsilon$ environments and on the streambed (arcsine-transformed data; $\mathrm{F}_{4,10}=7.8, P=0.004$ ) (figure 5D). Aluminum saturation was the lowest in the grassland as compared with the other environments $\left(\mathrm{F}_{4,10}=30.2, \mathrm{P}<0.001\right)$ (figure 5E). Finally, extractable aluminum was maximum on the forested slope and minimum in the floodplain $\varepsilon$ (Kruskal-Wallis test: $\mathrm{H}_{3,12}=9.5$, $P=0.02$ ) (figure 5F).

Soil texture was similar in the three environments at $5 \mathrm{~cm}$ depths, but when we considered the soil profile up to $50 \mathrm{~cm}$, some differences emerged. When comparing our main environments, the loam texture proportion was higher in the grassland, and the clay proportion was higher in the floodplain (table 1). There were significant differences in the proportions of textures among environments, within each textural class $\left(\mathrm{F}_{\text {environment }}=45.0\right.$ and 57.9 for loam and clay, respectively; $\mathrm{df}=2,18, P<0.0001$ in both cases). Although values found on the forested slope suggested that there was a greater proportion of sand in this site compared with the other two environments, the non-parametric ANOVA found no significant relationship for the main factors $\left(\mathrm{H}_{\text {environment }}=3.71, \mathrm{df}=2, P=0.156 ; \mathrm{H}_{\text {depth }}=5.69, \mathrm{df}=2\right.$, $P=0.058$; interaction term: $\mathrm{H}_{\text {environment } \mathrm{x} \mathrm{depth}}=11.06, \mathrm{df}=4$, $P=0.026)$.

Hydrological regime. Figure 2 shows that the groundwater level fluctuated according to the season: in the grassland it was 8-11 $\mathrm{m}$ a.s.1. in August, 7-9 $\mathrm{m}$ in December, and 6-8 m in May. Fluctuations were more dampened on the forested slope (4.7-5.5 $\mathrm{m}$ a.s.1.), as well as in the floodplain (less than
$40 \mathrm{~cm}$ of seasonal variation). Therefore, a hydraulic gradient existed between the grasslands and the floodplain despite that groundwater at $\delta$ wells was lower than at $\varepsilon$ wells in some exceptional cases. Furthermore, there was no hydraulic gradient when comparing the groundwater level in the wells adjacent to the stream $(\varepsilon)$ with the stream itself in winter, when the floodplain is inundated (figure 2, insert graph). There was a slight gradient in the direction of the stream in May, but the stream was higher than the $\varepsilon$ wells in April and December.

Streamflow responded within a lapse of hours after heavy rainfall and inundated the floodplain; this was compounded by the rainfall on this plain. We did not detect hillslope runoff, but groundwater seeped at the base of the slope in two sectors from July to October at a rate of approximately $4 \mathrm{~mL} \mathrm{~s}^{-1}$, which increased to $10 \mathrm{~mL} \mathrm{~s}^{-1}$ when it rained. This water was infiltrated again into the floodplain; however, the flow drained into the stream when the floodplain was saturated with water.

Trends in groundwater quality. Nitrite was found at negligible concentrations and is thus not shown. The nitrate-N concentrations were relatively low, with mean values lower than $120 \mu \mathrm{g} \mathrm{L}^{-1}$ and higher concentrations in May (figure 6A). Trends for different sampling dates were similar when decreasing concentrations were observed below the grassland, especially from -22.5 to $-7.5 \mathrm{~m}$ measured from the forest border, or from -7.5 to $0 \mathrm{~m}$. Diminution continued along the forested slope, and variations in nitrate- $\mathrm{N}$ concentrations were comparatively low in the floodplain forest. The creek showed an increase in this nutrient concentration as compared with the adjacent $\varepsilon$ wells ( $45 \mathrm{~m}$ from the forest border). The trend of ammonium-N concentrations was the

Table 1. Studied soils texture along a transect at the Austral Experimental Livestock and Agriculture Station, Valdivia. Values correspond to means \pm standard deviation of three replicates.

Textura de los suelos estudiados a lo largo de un transecto en la Estación Experimental Agropecuaria Austral, Valdivia. Los valores corresponden a promedios \pm desviación estándar de tres réplicas.

\begin{tabular}{|c|c|c|c|c|}
\hline Environment & Soil depth & Sand & Loam & Clay \\
\hline & $(\mathrm{cm})$ & $(\%)$ & $(\%)$ & $(\%)$ \\
\hline \multirow[t]{3}{*}{ Grassland } & 5 & $14 \pm 0.4$ & $60 \pm 0.4^{\mathrm{a}}$ & $26 \pm 0.4^{\mathrm{ad}}$ \\
\hline & 30 & $13 \pm 1.9$ & $59 \pm 2.8^{\mathrm{a}}$ & $28 \pm 2.1^{\text {abd }}$ \\
\hline & 50 & $22 \pm 1.7$ & $56 \pm 0.8^{\mathrm{a}}$ & $22 \pm 1.6^{\mathrm{d}}$ \\
\hline \multirow[t]{3}{*}{ Forested slope } & 5 & $12 \pm 0.02$ & $54 \pm 0.02^{\mathrm{a}}$ & $34 \pm 0.02^{\mathrm{b}}$ \\
\hline & 30 & $53 \pm 1.5$ & $37 \pm 2.3^{b}$ & $10 \pm 0.9^{c}$ \\
\hline & 50 & $49 \pm 3.9$ & $37 \pm 3.1^{b}$ & $13 \pm 0.9^{c}$ \\
\hline \multirow[t]{3}{*}{ Floodplain } & 5 & $15 \pm 0.3$ & $50 \pm 0.3^{\mathrm{a}}$ & $34 \pm 0.3^{b}$ \\
\hline & 30 & $13 \pm 0.7$ & $55 \pm 0.8^{\mathrm{a}}$ & $32 \pm 0.8^{\mathrm{ab}}$ \\
\hline & 50 & $15 \pm 1.6$ & $54 \pm 2.3^{a}$ & $31 \pm 2.3^{\mathrm{ab}}$ \\
\hline
\end{tabular}

Different superscripts indicate significant differences at $P<0.05$ according to the Tukey test after a two-way ANOVA (only comparisons within each textural class). No significant differences were detected for sand. 

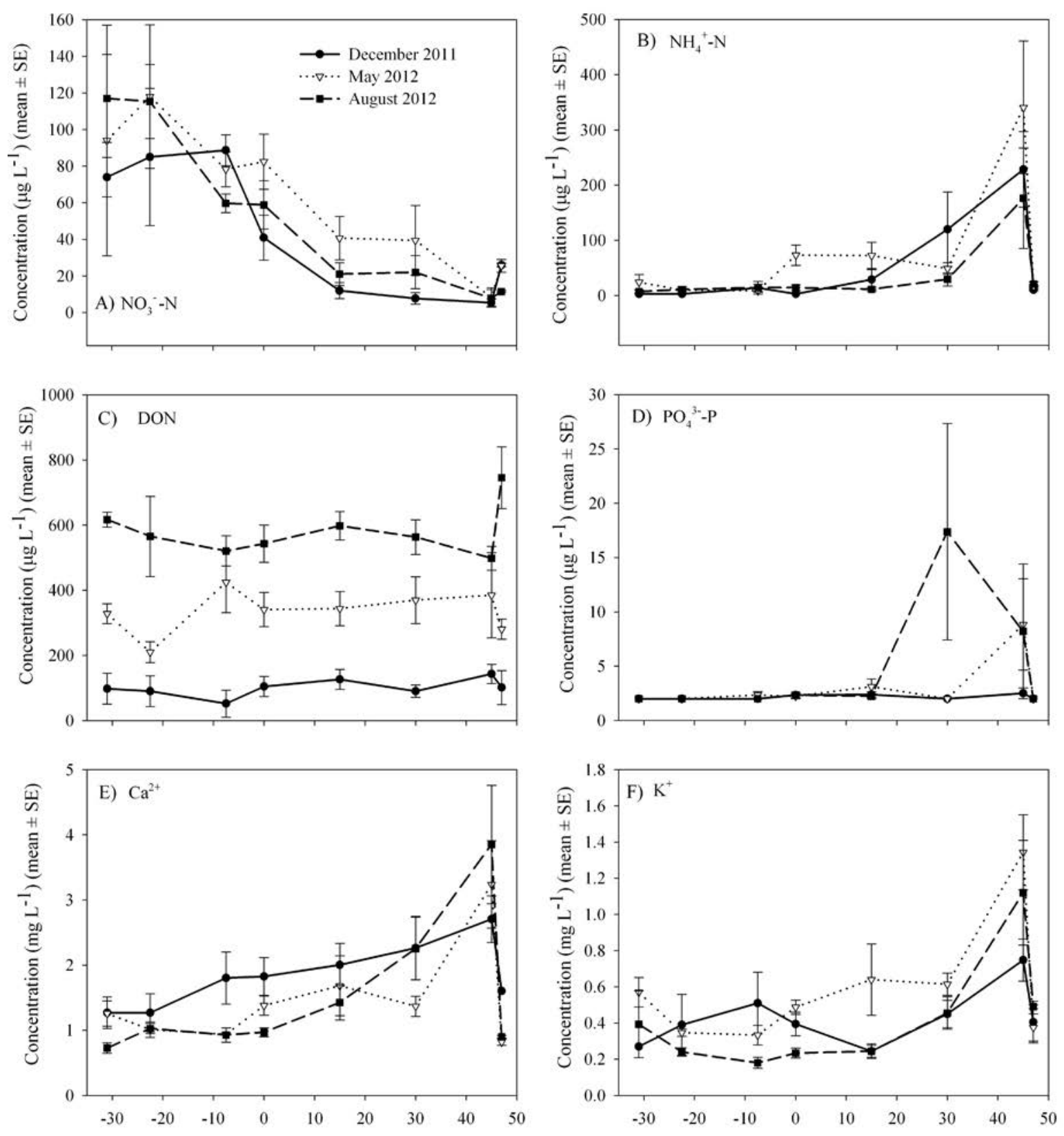

Distance to the grassland-forest border $(\mathrm{m})$

Figure 6.Trends in groundwater quality along a transect from grasslands to the Santa Rosa stream (last point on the right). The grassland-forest border corresponds to the meter 0 .

Tendencias en calidad del agua subterránea a lo largo de un transecto desde praderas hasta el arroyo Santa Rosa (último punto a la derecha). El borde bosque-pradera corresponde al metro 0 .

opposite of those for nitrate-N (figure 6B). There was little variation below the grassland, but the concentrations began to increase from the forest border, reaching a maximum at the $\varepsilon$ wells. The stream had lower ammonium-N concentrations than those presented by the forest $\left(10.5-21 \mu \mathrm{g} \mathrm{L}^{-1}\right.$ in the creek versus $176-340 \mu \mathrm{g} \mathrm{L}^{-1}$ in the $\varepsilon$ wells). Dissolved organic nitrogen showed no clear trend along the transect. The stream had concentrations very similar to those of the forest, except in August, when the creek showed its maximum concentration $\left(745 \mu \mathrm{g} \mathrm{L}^{-1}\right)$ (figure 6C).

Concerning phosphate-P, most mean values were quite similar along the transect and concentrations were very near the detection limit of the lab method $\left(2 \mu \mathrm{g} \mathrm{L}^{-1}\right)$ (figure $6 \mathrm{D})$. Interestingly, the highest concentrations were found in the floodplain (8-17 $\left.\mu \mathrm{g} \mathrm{L}^{-1}\right)$, but with high variance. Calcium concentrations showed a clearly increasing trend, 
especially in December, though the higher concentrations in the forest groundwater did not reach the stream (figure $6 \mathrm{E})$. Surface water mean values were 0.8 -1.6 versus 2.7 $3.8 \mathrm{mg} \mathrm{L}^{-1}$ in the $\varepsilon$ wells. Potassium trends were unclear in the December sampling; however they followed the calcium pattern in May and August (figure 6F). The highest values were found in May. For all dates the creek water had a lower concentration $\left(0.38-0.49 \mathrm{mg} \mathrm{L}^{-1}\right)$ than that found in the adjacent $\varepsilon$ wells $\left(0.75-1.34 \mathrm{mg} \mathrm{L}^{-1}\right)$. Sulfate concentrations showed scant variation along the transect, but stream levels were three times higher than in the forest (figure 7A). Finally, we found that there was no variation in chloride concentrations in the grassland or the forest, although it was clear that the forest showed higher chloride concentrations than those present in the grassland (figure 7B). We further analyzed this pattern by changing the hydrological tracer in August, and detected a slight trend of increasing concentration in direction to the floodplain, discounting the bromide peak at $-7.5 \mathrm{~m}$ (figure $7 \mathrm{C}$ ). Moreover, stream bromide concentrations were lower than in the forest.

The groundwater table depth can be derived from figure 2 in order to understand the main causes of groundwater patterns. In the grassland, the groundwater depth was 7.4$8.2 \mathrm{~m}$ below ground in December, increasing to 8.4-9.3 m in May, and achieving a minimum in August (5.3-7.6 m). At the forest border, groundwater depth was $8.4 \mathrm{~m}$ (December), $9.4 \mathrm{~m}$ (May) and $7.7 \mathrm{~m}$ (August). In the forested slope, levels were between 5 and $6 \mathrm{~m}$ for the three sampling dates. Finally, in the floodplain, water was less than $30 \mathrm{~cm}$ below the ground; even in $\varepsilon$ wells water was above ground (mean $5 \mathrm{~cm}$ ) due to the swollen stream in August.

Electrical conductivity. This variable showed similar trends for the different sampling dates (figure 8). In May 2012, the electrical conductivity values increased from a mean of 42 $\mu \mathrm{S} \mathrm{cm}^{-1}$ in the uplands to $128 \mu \mathrm{S} \mathrm{cm}^{-1}$ in the $\varepsilon$ wells. On August $24^{\text {th }}, 2012$ the range of variation was from 24 to $88 \mu \mathrm{S}$ $\mathrm{cm}^{-1}$ and a few days later it was 24 to $151 \mu \mathrm{S} \mathrm{cm}^{-1}$ in the same transect. The creek, which is located $2 \mathrm{~m}$ away from $\varepsilon$, showed a drastic reduction in conductivity $\left(33-36 \mu \mathrm{S} \mathrm{cm}^{-1}\right)$, that is $22-37 \%$ compared with the $\varepsilon$ wells.

Nutrient variations along the stream. In general, none of the nutrients showed a marked pattern of variation along the stream transect, which was confirmed by the low determination coefficients observed $\left(r^{2} \leq 0.38\right.$, figure 9$)$. The only exception was nitrate- $\mathrm{N}$, which showed $\mathrm{r}^{2}=0.61$, but all linear models were not statistically significant $(P>0.12)$. Therefore, any trend of variation, whether increasing or decreasing, was very slight in the studied 2,000 m-transect.

\section{DISCUSSION}

Soil analyses. Our results showed that most soil variables changed significantly with maximum values generally found in the floodplain (except nitrate-N, which did not vary sig-
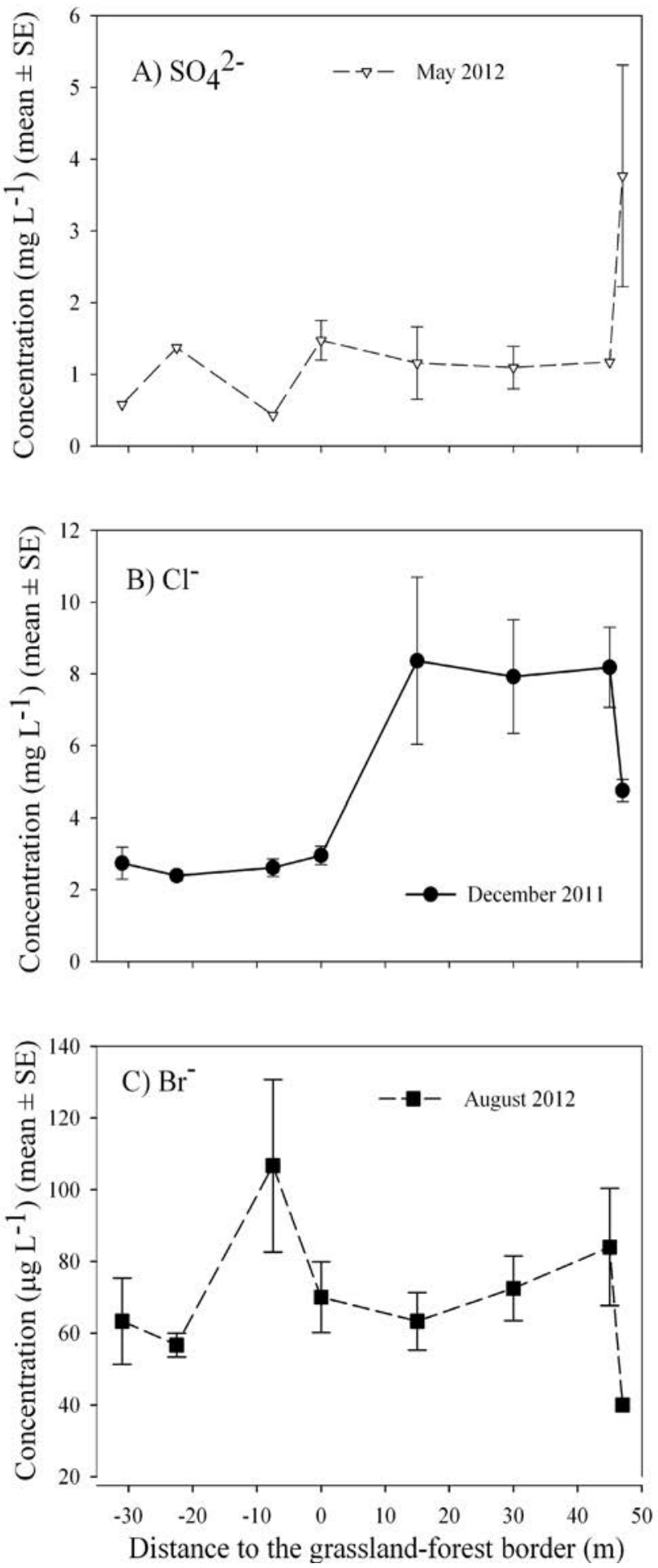

Figure 7. Trends in groundwater quality for sulfate and two hydrological tracers in a transect going from grasslands to the Santa Rosa stream (last point on the right).

Tendencias en calidad del agua subterránea para el sulfato y dos trazadores hidrológicos en un transecto desde praderas hasta el arroyo Santa Rosa (último punto a la derecha). 


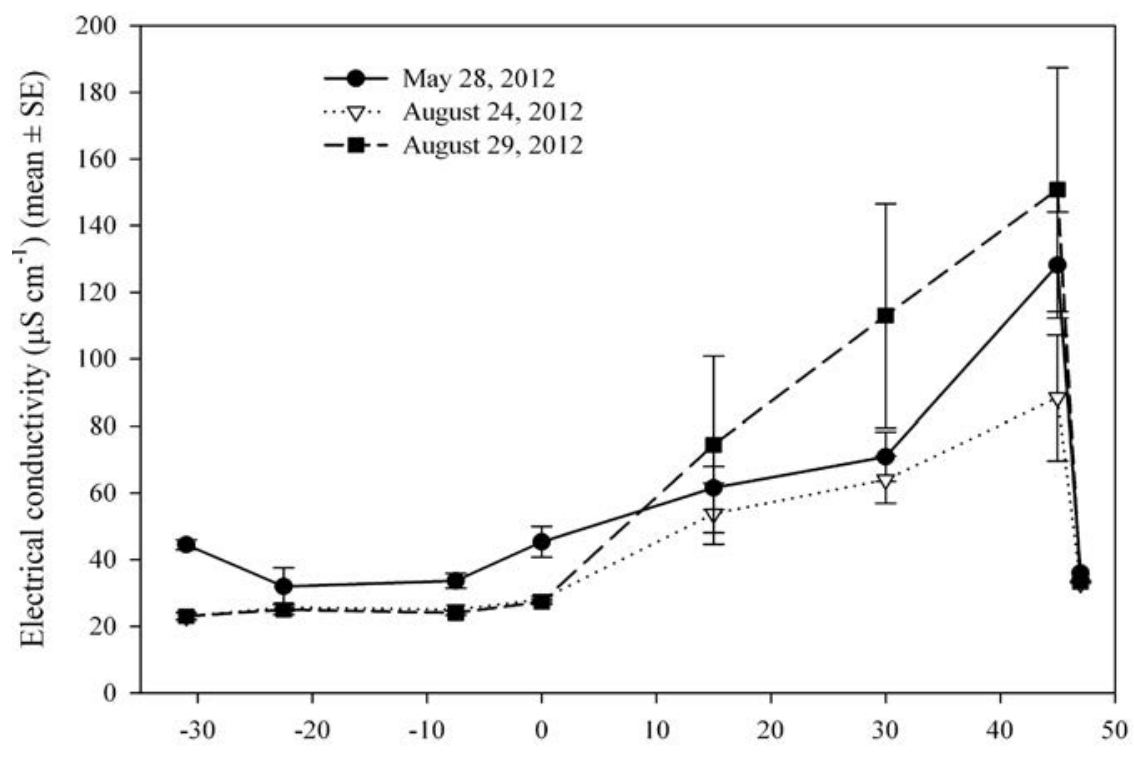

Distance to the grassland-forest border (m)

Figure 8. Groundwater electrical conductivity referred to as $25^{\circ} \mathrm{C}$ in a transect going from grasslands to the Santa Rosa stream (last point on the right, surface water).

Conductividad eléctrica del agua subterránea referida a $25^{\circ} \mathrm{C}$ en un transecto desde praderas hasta el arroyo Santa Rosa (último punto a la derecha, agua superficial).

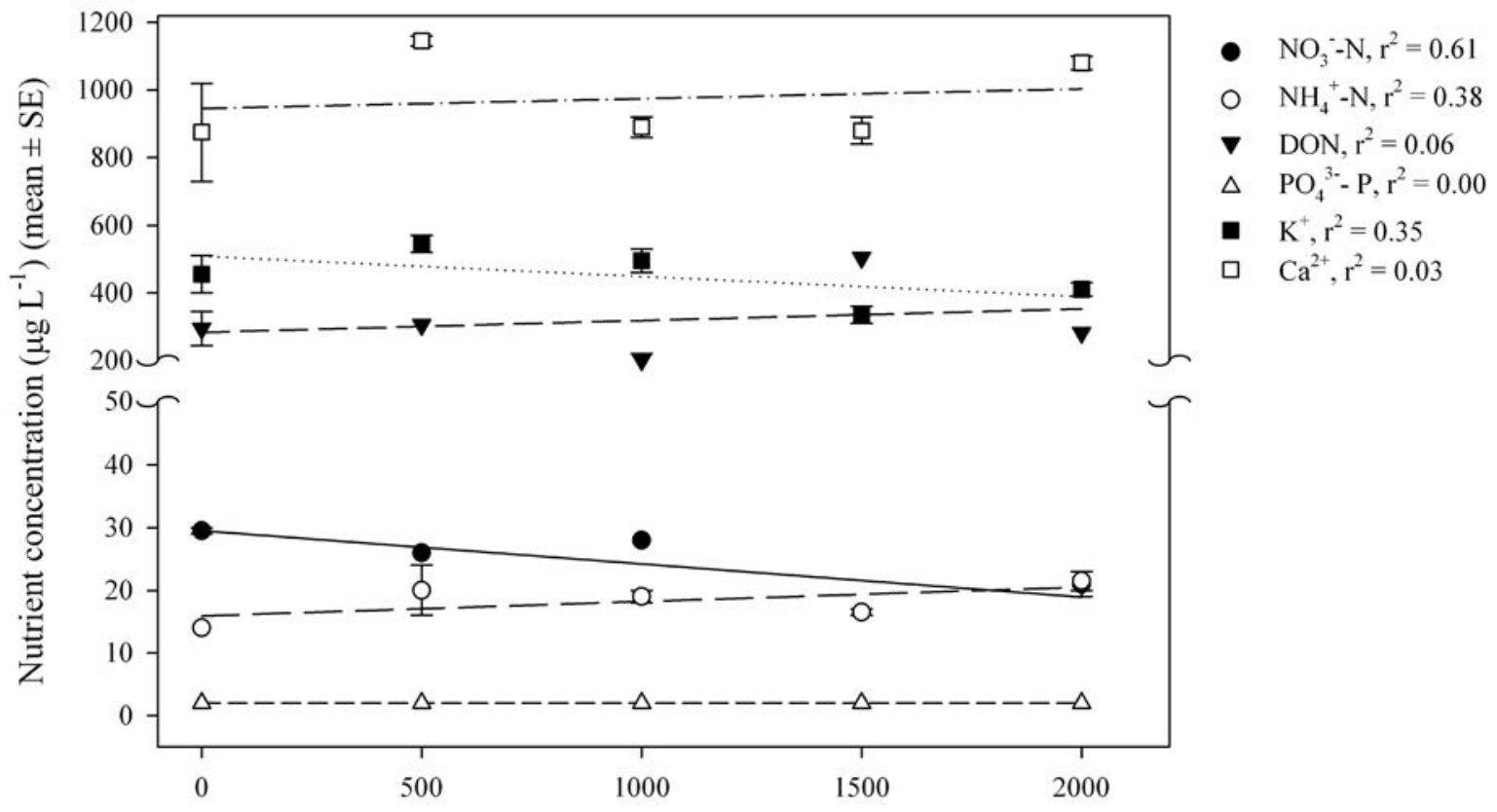

Distance upstream from watershed outlet $(\mathrm{m})$

Figure 9. Trends in nutrient concentration in the Santa Rosa stream surface water, along a transect beginning 2,000 $\mathrm{m}$ upstream from the watershed outlet (meter 0 ). Note that flow direction is from right to left. $\mathrm{r}^{2}=$ coefficient of determination.

Tendencias en concentración de nutrientes del agua superficial del arroyo Santa Rosa, a lo largo de un transecto comenzando $2.000 \mathrm{~m}$ corriente arriba de la salida de la cuenca (metro 0). La dirección de flujo es desde la derecha a la izquierda. $\mathrm{r}^{2}=$ coeficiente de determinación. 
nificantly). This means that even though the soils belong to the same Valdivia series, important differences along a transect from upland areas to streambeds were found. We also discovered an unexpected variation in phosphorus retention: the extractable aluminum values above $1,000 \mathrm{mg} \mathrm{kg}^{-1}$ found in both the grasslands and the forested slopes are typical for allophanic soils implicated in high phosphorus retention (Rodríguez et al. 2001, Alfaro et al. 2008). Generally, the higher Olsen phosphorus concentrations were inversely correlated with extractable aluminum, but grassland avoided this trend. Past fertilization practices may explain the higher amounts of Olsen phosphorus found in the grassland.

Floodplain soils were significantly more acidic than upland soils and showed higher soil organic matter, which is coherent with the higher input of litter produced by trees growing in the floodplain compared with the grasslands, whose production was removed every time the grass was cut. Humus produced by forests also tends to acidify the soil, among other factors (Brady and Weil 2004). Another reason for this pattern could be past periodic liming of the grassland.

Ammonium- $\mathrm{N}$ accumulation in the floodplain, as compared to the uplands, may be related to the lower $\mathrm{pH}$ found in that area. Some studies have reported that the microbial conversion from ammonium to nitrate decreases at low $\mathrm{pH}$ levels and when exposed to the anoxic conditions found in temporally flooded soils (Dierberg and Brezonik 1982). This is reasonable considering that the groundwater level was never deeper than $63 \mathrm{~cm}$ below floodplain $\varepsilon$ ground. Furthermore, ammonium does not leach as easily as nitrate (Brady and Weil 2004). Notwithstanding, the nitrogen cycle is complex and we cannot discard that other pathways that converge with ammonium may be affected (e.g., increased ammonification from organic matter). Furthermore, Dhondt et al. (2006) and Huygens et al. (2008) point out that an increased dissimilatory nitrate reduction to ammonium (DNRA) is a possible mechanism responsible for removing nitrate from the soil pool, mainly in anoxic microsites, including riparian zones. The special physical properties of southern Chile volcanic soils are associated with some level of ecosystem resilience and provide a favorable condition for nitrogen conservation, which has been related to the abiotic adsorption of ammonium in soil particles, nitrogen microbial immobilization and, to a certain extent, DNRA processes (Huygens et al. 2007). Even though these phenomena were not studied along the same transect beginning in the grasslands, they were proposed as ecosystem state variables capable of indicating the probability of an ecosystem to lose nitrogen.

The behavior of ammonium, basic cations, exchangeable aluminum and aluminum saturation is fairly coherent with a nutrient enrichment occurring in the floodplain soils. We hypothesized that cationic exchange capacity could be responsible for this high retention, but we found marginal differences among environments. Assuming that this result was not caused by a low sample size $(\mathrm{n}=3)$, other causes may be involved (see below).
A possible limitation of the soil analyses protocol at $0-20 \mathrm{~cm}$ could have been the fact that grassland soil was sampled relatively far from groundwater, while floodplain soil was sampled close to groundwater. However, several publications show that nitrogen, phosphorus, and potassium concentrations decrease with an increase in depth, while calcium has scant variations. Only chloride, sulfate and $\mathrm{pH}$ show an increasing trend (Jobbágy and Jackson 2001, Brady and Weil 2004). Therefore, if all soil analyses had been carried out close to groundwater, we would expect increasing trends in nutrient concentration (and the opposite for $\mathrm{pH}$ ) to be sharper than those reported here in the transect. On the other hand, the liming of grasslands increases the $\mathrm{pH}$, which is positively related to the cationic exchange capacity (Brady and Weil 2004), making the expected increasing trend towards floodplains more difficult to detect.

The soil texture changed from a prevailing loamy texture in the grassland to a higher proportion of sand in the forested slope (>30 cm depth) and an increased clay proportion in the floodplain. These patterns, in addition to soil organic matter accumulation in this area, were marginally associated with a differential cationic exchange capacity along the transect.

Trends in groundwater quality: nitrate. The decreasing trend in nitrate-N levels in the studied transect may have several explanations. We studied the groundwater depth to evaluate whether plant roots could contact the saturated zone. In grasslands, groundwater was at least $5 \mathrm{~m}$ below ground, out of the reach of grass roots, which is only $1.8 \mathrm{~m}$, with $73 \%$ of root dry weight between 0 and $30 \mathrm{~cm}$ depths (Wedderburn et al. 2010). Therefore, grasses could not modify nutrient concentration once water had percolated below these depths. At the forest border and in the forested slope, groundwater was between 5 and $9 \mathrm{~m}$ below ground. There is no significant literature dealing with tree roots maximum depth in Chilean species, but we noticed that the dominant tree ( $N$. obliqua) did not penetrate deeper than 4 $\mathrm{m}$ after drilling the wells in the present investigation. Even assuming that roots could eventually reach the capillary fringe close to groundwater at a depth of $5 \mathrm{~m}$, it is uncertain whether this may be an important source of water uptake, considering that the species found on this slope have not been classified as phreatophyte. On the contrary, in the floodplain, water is near the surface, and Myrceugenia exsucca, Blepharocalyx cruckshanksii and Drimys winteri trees have no problem reaching it. In fact, we found many roots underwater during well construction. These species are more likely to be phreatophytes, although scientific evidence is lacking. However, interestingly the strongest variation in nitrate- $\mathrm{N}$ was not produced in this area but in the forested slope and in the grassland. This suggests that vegetation itself is not as related to nitrate sinks as other possible processes might be: immobilization by soil microbes as well as intensified conversion to ammonium (DNRA), which were reported in riparian zones (Dhondt 
et al. 2006). Huygens et al. (2008) have also suggested a nitrate immobilization in soluble organic nitrogen fractions in the soil of non-riparian environments. Lastly, only spring denitrification could contribute to higher nitrogen escape from the floodplain, since no differences in nitrous oxide emissions were found in the studied transect throughout most of the year ${ }^{3}$. These processes, not related directly to plant uptake, contrast with other studies carried out in soils with shallower groundwater (Lowrance 1998), where trees are considered of prime importance in nutrient retention.

On the other hand, the creek showed an increase in nitrate concentrations compared to groundwater in adjacent $\varepsilon$ wells, contrary to other evaluated nutrients patterns. However, we must consider that the creek receives its water supply from the whole watershed. The specific $200 \mathrm{~m}$ segment of streamside vegetation that we have evaluated may be not representative of all of the influences that the stream receives, considering, for example, that the studied grasslands were not fertilized in the reported period of groundwater analyses, contrary to the rest of the experimental station grasslands.

Trends in groundwater quality: other nutrients. The high ammonium-N levels in the floodplain groundwater may be related to the accumulation of this cation in the soil, as previously discussed. The lack of dissolved organic nitrogen variation along the transect, in spite of the nitrate-N and ammonium-N trends, supports Huygens et al. (2008) statement that dissolved organic nitrogen biogeochemistry is independently regulated in relation to inorganic nitrogen trends.

The general lack of variation of phosphate-P along the studied transect agrees with an expected high phosphorus adsorption to volcanic soils in the area. Moreover, our results for high soil extractable aluminum are coherent with low groundwater phosphate-P concentrations (higher phosphorus retention) in the grasslands and the forested slope, while the opposite was found in the floodplain.

Groundwater trends for ammonium, calcium and potassium, along with the soil chemistry results, further suggest that the forest, and particularly the floodplain forest, is acting as a nutrient accumulator. This observation is also supported by: i) chloride and bromide hydrological tracers, given that chloride clearly increased from grasslands to forest, and bromide showed a slighter increasing trend; ii) the electrical conductivity, which increased from uplands to floodplain, reached a maximum at the well immediately adjacent to the stream. These conclusions are in line with previous studies in the United States (Noe and Hupp 2005).

Hydrological regime. On a regional scale, groundwater flows to the stream and behaves as a gaining stream. However, on the experimental site scale, groundwater flows mainly on the hill-slope. The low or even reverse gradient between stream banks and the creek means that groundwater discharge into the stream is likely very low

L. Paulino et al., unpublished data. as compared with the streamflow; therefore, groundwater quality does not affect stream quality. If we assume that the hydrology of the study site is not typical of the entire watershed and that its exfiltration rates are higher upstream, then under a no soil nutrient retention scenario, the stream water nutrient concentration would progressively increase throughout its course. This possibility was discarded given the non-significant variation of nutrient concentration that was found. Floodplains also receive water nutrients and sediments coming from upstream (approximately 0.23 - 210 $\mathrm{kg} \mathrm{d}^{-1} \mathrm{ha}^{-1}$ depending on the season, unpublished results); these sediments are rich in minerals (Naiman et al. 1998) and contribute to nutrient accumulation in floodplain soils. Therefore, it remains to be explained why groundwater discharged into the stream partially loses its nutrient charge before entering the stream. These patterns highlight the role of floodplain soils in nutrient retention, and establish a link between water and nutrient fluxes coming from close uplands or microcatchment headwaters.

Review of our hypotheses. Our results for nitrate-N are coherent with our first hypothesis, regarding the tight nitrogen cycle in Chilean forests, but the tree effect is not clearly observed. On the other hand, ammonium-N meets our expectations, explained by the soil filtration role, but not the dissolved organic nitrogen due to decoupling between inorganic and organic nitrogen forms. Our study documented a very low phosphate-P loss, as expected from our second hypothesis in relation to high phosphorus adsorption to volcanic soils. Finally, basic cations have been shown to increase in transects from uplands to streams, the pattern that was expected in the third hypothesis. Notwithstanding, stream water was cleaner than floodplain groundwater. Once again, soil properties appear to be involved although more data are needed to speculate on the relative role of cationic exchange capacity versus other causal factors.

Concluding remarks. We expected the Nothofagus obliqua forest growing on the slope, and the riparian forest growing in the floodplain to play a more significant role in nutrient filtration than that played by grasslands, due to the differential growth rates and root scopes, in addition to mycorrhizae associated with trees. However, in the studied ecosystem, the role of second-growth trees does not seem to be as directly related to the buffer effect as is the soil, probably due to large groundwater depths in relation to trees roots. This does not imply that trees are unimportant for the ecosystem functions in Chilean riparian zones; in fact, they stabilize soils, provide habitat for microbial communities in the rhizosphere, determine soil properties, recycle nutrients and regulate the forest microclimate. Thus, the biogeochemical antecedents presented in this paper support the conservation of forest environments surrounding streams, which face pressure from productive land uses, such as grasslands, tree plantations, crops, and urban settlements. Moreover, native forests must be protected from browsing and tree felling 
for ecosystem functions to work properly. Finally, the forest effect on streams must be understood as the integrated influence of the entire ecosystem, not only the tree effect.

\section{ACKNOWLEDGMENTS}

Funding for this research was provided by Fondecyt grant 1110156. We thank to Santa Rosa Experimental Station staff for their help, especially Administrators Rodrigo Barriga and Carlos Villagra. The Garden Unit of Universidad Austral also contributed with grass maintenance. Mr. Fernando Rodríguez, Profs. Víctor Gerding, Carlos Le Quesne, Juan Nissen, Dante Pinochet and Mrs. Reydoret Umaña are also acknowledged for several interesting discussions about our results. The comments made by three anonymous reviewers are also appreciated.

\section{REFERENCES}

Alfaro M, F Salazar, S Iraira, N Teuber, D Villarroel, L Ramírez. 2008. Nitrogen, phosphorus and potassium losses in a grazing system with different stocking rates in a volcanic soil. Chilean Journal of Agricultural Research 68: 146-155.

Amigo J, C Ramírez. 1998. A bioclimatic classification of Chile: woodland communities in the temperate zone. Plant Ecology 136: 9-26.

APHA (American Public Health Association, US). 2005. Standard Methods for examination of water and wastewater, 21st edn. Washington, DC. American Public Health Association. 1263 p.

Brady NC, RR Weil. 2004. Elements of the nature and properties of soils, 2nd edition. Upper Saddle River, New Jersey. Pearson-Prentice Hall. 606 p.

DGA (Dirección General de Aguas, Ministerio de Obras Públicas, CL). 2007. Manual de normas y procedimientos del Departamento de Conservación y Protección de recursos hídricos. Santiago, Chile. DGA. 182 p.

Dhondt K, P Boeckx, N Verhoest, G Hofman, O Van Cleemput. 2006. Assessment of temporal and spatial variation of nitrate removal in riparian zones. Environmental Monitoring and Assessment 116: 197-215.

Dierberg F, PL Brezonik. 1982. Nitrifying population densities and inhibition of ammonium oxidation in natural and sewage-enriched cypress swamps. Water Research 16: 123-126.

Dörner J, D Dec, X Peng, R Horn. 2009. Change of shrinkage behavior of an Andisol in southern Chile: Effects of land use and wetting/drying cycles. Soil \& Tillage Research 106: 45-53.

Forsythe W. 1974. Manual de laboratorio de física de suelos. Turrialba, Costa Rica. Instituto Interamericano de Ciencias Agrícolas de la Organización de los Estados Americanos. $212 \mathrm{p}$.
Hedin L, J Armesto, A Johnson. 1995. Patterns of nutrient loss from unpolluted old-growth temperate forests: evaluation of biogeochemical theory. Ecology 76: 493-509.

Huygens D, T Rütting, P Boeckx, O Van Cleemput, R Godoy, C Müller C. 2007. Soil nitrogen conservation mechanisms in a pristine south Chilean Nothofagus forest ecosystem. Soil Biology \& Biochemistry 39: 2448-2458.

Huygens D, P Boeckx, P Templer, L Paulino, O Van Cleemput, C Oyarzún, C Müller, R Godoy. 2008. Mechanisms for retention of bioavailable nitrogen in volcanic rainforest soils. Nature Geoscience 1: 543-548.

Jobbágy EG, RB Jackson RB. 2001. The distribution of soil nutrients with depth: Global patterns and the imprint of plants. Biogeochemistry 53: 51-77.

Lowrance R. 1998. Riparian forest ecosystems as filters for nonpoint-source pollution. In Pace ML, PM Groffman eds. Successes, limitations, and frontiers in ecosystem science. New York, USA. Springer. p. 113-141.

Naiman R, K Fetherston, S Mckay, J Chen. 1998. Riparian forests. In Naiman R, R Bilby eds. River ecology and management: lessons from the Pacific Coastal Ecoregion. New York. Springer. p. 289-323.

Noe G, CR Hupp. 2005. Carbon, nitrogen, and phosphorus accumulation in floodplains of Atlantic coastal plain rivers, USA. Ecological Applications 15: 1178-1190.

Pérez C, M Carmona, J Armesto. 2003. Non-symbiotic nitrogen fixation, net nitrogen mineralization and denitrification in evergreen forests of Chiloé Island, Chile: a comparison with other temperate forests. Gayana Botanica 60: 25-33.

Rodríguez J, D Pinochet, F Matus. 2001. Fertilización de los cultivos. Santiago, Chile. LOM Ediciones. 117 p.

Sadzawka A, M Carrasco, R Grez, M Mora, H Flores, A Neaman. 2006. Métodos de análisis recomendados para los suelos de Chile. Serie Actas INIA No. 34. Santiago, Chile. Instituto de Investigaciones Agropecuarias. 164 p.

Sokal R, F Rohlf. 1995. Biometry. The principles and practice of statistics in biological research. 3rd ed. New York, USA. WH Freeman and Company. 887 p.

Strayer DL, RE Beighley, LC Thompson, S Brooks, C Nilsson, G Pinay, RJ Naiman. 2003. Effects of land cover on stream ecosystems: roles of empirical models and scaling issues. Ecosystems 6: 407-423.

Weathers K, G Lovett, G Likens, N Caraco. 2000. Cloudwater input of nitrogen to forest ecosystems in southern Chile: forms, fluxes, and sources. Ecosystems 3: 590-595.

Wedderburn M, J Crush, W Pengelly, J Walcroft. 2010. Root growth patterns of perennial ryegrasses under well-watered and drought conditions. New Zealand Journal of Agricultural Research 53: 377-388.

WRB (World Reference Base for Soil Resources, IT). 2006. World reference base for soil resources 2006. A framework for international classification, correlation and communication. 2nd ed. World Soil Resources Reports No. 103. Rome, Italy. FAO. 128 p. 